\title{
Positive Effect of Industry 4.0 on Quality and Operations Management
}

\author{
https://doi.org/10.3991/ijoe.v17i09.24717 \\ Hanane Rifqi $\left.{ }^{\bowtie}\right)$, Abdellah Zamma, Souad Ben Souda, Mohamed Hansali \\ HASSAN II University, Casablanca, Morocco \\ hanane.rifqi.14@gmail.com
}

\begin{abstract}
- the last decade has witnessed the birth of technological advances such as the IoT, artificial intelligence, machine learning and augmented reality. These technologies have driven the transition to Industry 4.0 where they have enabled the digitization of manufacturing with potential gain. Also Industry 4.0 has given birth to several new hybrid concepts as well as several management operations to take advantage and become more efficient by using IoT and these new technologies. In our paper, we discuss the effect of Industry 4.0 on management and quality practices by answering the following questions based on the literature review: What is the positive effect of Industry 4.0 on quality improvement and operations management? How does Industry 4.0 integrate concepts (Lean, Six Sigma, Supply Chain ...) to create new paradigms?
\end{abstract}

Keywords-Industry 4.0, Technologies, Quality Improvement, Quality 4.0, Lean Manufacturing, Six Sigma, Big Data, IoT, review.

\section{Introduction}

Industry 4.0 represents a transformation in how manufacturing companies do business and a significant opportunity to apply innovation to companies, industries, and economies[1].In this context that today's manufacturing companies must produce the highest quality products in order to meet the ever-increasing demands of customers and still be competitive.

The integration aspects of Industry 4.0, rising customer expectations, global competition and ever-increasing product complexity are the reasons why quality management has become indispensable in today's companies and quality has become an integral part of corporate goals, strategies and policies [2].

Industry 4.0 is a very large area that includes: production processes, efficiency, data management, consumer relationship, competitiveness, and much more. At the same time, it is evident that Industry 4.0 has become a new topic for management scholars and business economics disciplines and a number of contributions covering various problems and aspects that have been published [3].

It was assumed that the term "4.0" combined with other words had been used by researchers to determine new concepts that were defined by the authors of the paper as 
"Industry 4.0 sub-papers". As a result, a list of Industry 4.0-based concepts was identified $[4$, p. 0$]$.

This article will discuss the effect of Industry 4.0 and its technologies on operations management, especially for the lean, supply chain management and six sigma concepts that have been able to take advantage of the digitalization and the specific tools of Industry 4.0 to meet the new environmental challenges. Also, the evolution of quality towards the new concept 'quality 4.0 ' will be discussed. This new perspective of quality, which can allow companies to see an increase in efficiency of $80 \%$ and an increase in productivity of $50 \%$ [5].

This paper includes four sections to allow a detailed view on the relevance of Industry 4.0 on quality improvement and management methods. After this introduction, the second section includes a literature review on the three main axes which are industry 4.0, quality development and various management methods. In the third section we outline the context of Industry 4.0 to create hybrid models such as Quality 4.0, Lean Sigma 4.0 and other operational management models. A conclusion and research perspectives will be presented in the fourth and last section.

\section{$2 \quad$ Literature review}

\subsection{Industry 4.0}

"Industry 4.0", "Production 4.0", Integrated Industry" "Digital Factory", "Interconnected Factory", "Smart Factory, "Digital Manufacturing," " and "Human-Machine Cooperation "are all names that refer to the fourth industrial revolution [6]that first appeared in Germany [7]. From industry 1.0 with the discovery of coal to the fourth revolution where digitalization is its main feature, several factors that led to this transition such as: competition, globalization, and consumer demands.

Industry 4.0 is very well known by the diversification and power of its tools and techniques, such as Internet of Things IoT, Big data analytics, artificial intelligence, Deep learning, etc. (see figure 1)[8, p. 0], [9]. These technologies that have made networks and products more intelligent [10] and also have participated in the emergence of several concepts such as Lean Six Sigma4.0, Lean 4.0, sustainability 4.0, agile 4.0, maintenance 4.0, logistics 4.0, supply Chain Management 4.0, quality 4.0 and others that are trying to be adapted to this new digital environment.

The use of Industry 4.0 tools and techniques has been proven in the literature via the huge number of publications. The proven benefits have encouraged researchers and industrialists to produce and participate in the research of this field where the papers production on Industry 4.0 during the year 2019 on the databases of both Wos and SCOPUS journals has witnessed a significant increase compared to the last years [4]. 


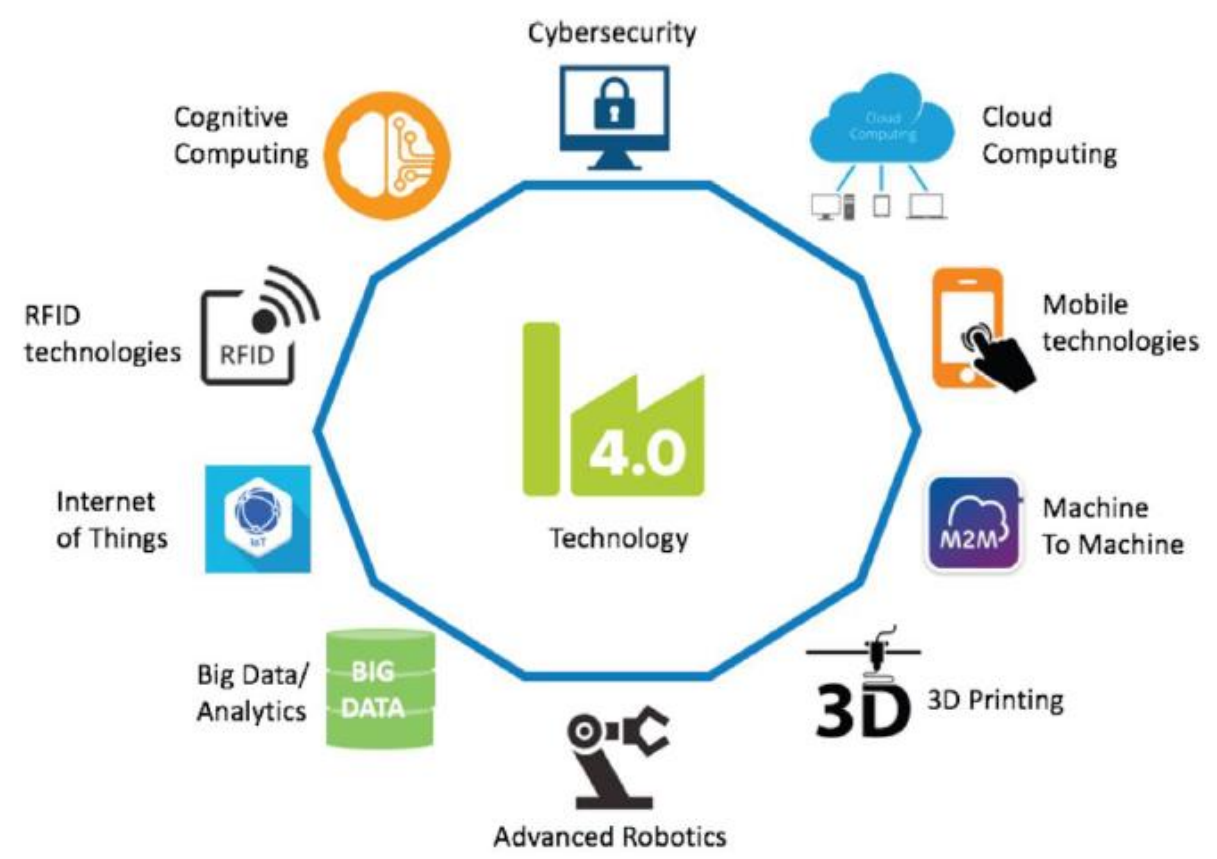

Fig. 1. The different Industry 4.0 technologies [11]

For the results published in the literature and which concern the industrial environment, the companies which follow the industry 4.0 can minimize their costs of logistics between $10 \%$ and $30 \%$, the costs of production between $10 \%$ and $30 \%$, the costs related to the management of quality from $10 \%$ to $20 \%$ [12], and by respecting the requirements of the industry 4.0 standard companies will have an impact on [13]:

- Conditions of qualification,

- Quality of work,

New ways of organizing work and modifying many interactions in the man-machine interface that we can guess as new forms of collaborative work in the context of a digital factory.

\subsection{Quality improvement \& control}

Quality is an old term that was born with human and represents a perfect image of the wished good. However, nowadays quality and its achievement has become a challenge for all types of industries. Adding that the factors that allow the efficiency achievement and the competitiveness maintain in the organizations possess a quality obtained at lower costs, by the minimization of the wastes, the optimization of the chain of the value and a quality mainly oriented to the customer [14]. This is achieved through the deployment of quality management and operations management models, quality management systems, quality control improvements, the development of quality 
improvement or customer satisfaction plans and strategies, or the deployment of quality improvement methods.

In the beginning, the roots of many quality improvement approaches can be traced back to production quality control thinking that emerged in the early 1920s [15], via the statistical theory which is applied for the protection of the quality aspect of the products. In 1924, Dr. Shewhart was able to develop a quality control chart which is later in 1940 framed in the theory of Statistical Process Control (SPC) by the father of quality Dr. Deming, towards more developed quality management practices by Japanese industries in the 1950s as in all nations, to 1960 s where quality control and management became a choice for industries [16], [17]. From this period to the present day a set of systems, methods, models, approaches and tools have been invented in favor of quality improvement. In addition, the last decades have seen many methods of quality control that have been studied as well as many researches are conducted in the field of quality control for the purpose of improving the production rate and efficiency and to reduce costs [18].

Quality control is one of the four concepts of quality management [2] which groups several techniques, generally statistical, applied to improve the quality of the manufacturing process by a very reduced variability [19]. Currently, one of the major challenges in the manufacturing industry is a fast and accurate inspection that guarantees the highest standards and quality requirements at a very competitive price [20]. Even for the supply chain of any company, it is judged efficient and optimized mainly according to the quality control factor [21].

In the industry 4.0 era, quality like all other concepts can benefit from the new technologies for a better exploitation of the new sources and the important number of data collected, especially to detect defects that were previously undetectable. The literature also offers many studies and papers that address the gaps in quality control and quality assurance through the deployment of the CPS that can identify and route products and participate in the management of gauges and tools [22]. However, the quality control also meets several challenges during its integration with this new paradigm "industry 4.0" either in the lack of information feedback, the required data quality, the low processing capacity, the lack of connection between the operator and the system and other challenges related to the improper use of technologies or data exploitation [23].

\subsection{Operation management}

The product customization with high quality, reduced deadlines and prices, industrial digitalization, environmental considerations and other factors have forced today's companies to think about adopting operations management approaches in order to properly manage the operations of the different processes that they manage. Especially since operations represent one of the three strategic functions of any organization (see figure 2). This means that it is a vital element in achieving the organization's strategy and ensuring its long-term survival, in particular because operations focus on the process effectiveness and efficiency [24], [25].

The operation management OM can probably be considered as a mixture of behavioral and natural sciences [26]. This management can reduce lead times either in 
production or delivery, reduce time to develop and commercialize new products, flexibly adapt production capacity and finally improve reliability and reduce costs, as well as improve the quality of services and products [27], [28]. To accomplish these goals, there exist different operations management approaches that allow the improvement of several processes, where we introduce the most general ones such as the Business Process Management BPM approach, World Class Manufacturing WCM approach, Total Quality Management TQM approach, Lean Six Sigma LSS approach, Total Productive Maintenance TPM approach, Supply Chain Management SCM approach, etc.

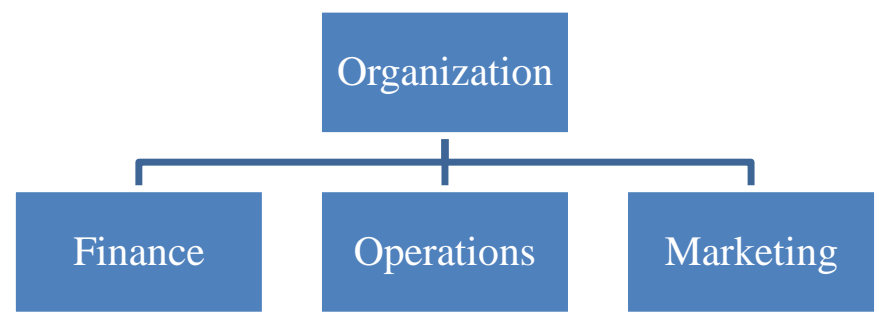

Fig. 2. The three strategic functions of any organization [24]

With each industrial revolution, the concepts of MO are evolving between traditional and modern models, where the field of management does not cease to improve and incorporate new concepts, approaches and methodology [29]. The MO uses as a basis the results of scientists from different fields, from those of Adam Smith to the use of modern information and communication technologies [30], as there are researches that have associated different approaches like lean production, business process reengineering (BPR), SCM and e-business closely with MO [31].

In operations departments, quality is one of the main concerns especially since quality control is part of the main operations management functions and within its different approaches we find a set of approaches that are dedicated to quality management. These approaches that are initiated by various experts such as Taguchi, Deming, Shewhart, Juran, and others, they have established the basis of the quality approach practiced in the different sectors [32], as well as by their participation in the foundations of quality management and continuous improvement

\section{Quality and management in the industry 4.0 era}

\subsection{Quality 4.0}

The term "quality 4.0" is one of the concepts related to the emergence of Industry 4.0 where the new technologies allow a real-time control via IoT with no required human intervention. This term which was predicted by Watson (1998) more than 20 years ago, for an automated quality through developed machines as well as through the increasing availability of telecommunication technologies, personal computing, Internet and networks [33]. Industry 4.0 has also enabled the transformation of the quality to a 
predictive quality, that is predicting the accurate state and outcome of the product from the start [34].

Quality 4.0 Q4.0 is a strong new revolution of quality. However, it will not replace its traditional methods, but rather improve and develop them through automation, connectivity and digital access capacity. For example, the SPC should be improved in terms of efficiency and productivity[35]. We can also consider that Q4.0 is the digitalization of the Total Quality Management TQM and its impact on the quality of technologies, processes and people [36]. Its application can take different aspects, Sader et al. [37] provide a framework for integrating Industry 4.0 and its features with TQM and its principles, where integration, inter-connectivity and big data can participate in improving the implementation of quality management approaches (see figure 3 ).

The term quality 4.0 includes not only the combination of TQM and Industry 4.0 but rather several benefits related to quality. Nenadál [38] unveiled a set of characteristics related to the new concept quality 4.0 where we find that:

- Quality 4.0 is a general term that describes a new approach to managing all quality requirements via data.

- Industry 4.0 addresses all issues related to quality and its management in the digital age.

- Quality 4.0 includes four main areas to be addressed and which are: development, design, production, service and finally the corporate culture.

- Human knowledge for the evolution from traditional quality to Quality 4.0

- Quality 4.0 effectively combines the methods and tools of quality management with the new technologies of Industry 4.0 (machine learning, Internet of Things, cloud computing, artificial intelligence, big data, etc.) (see table 1)

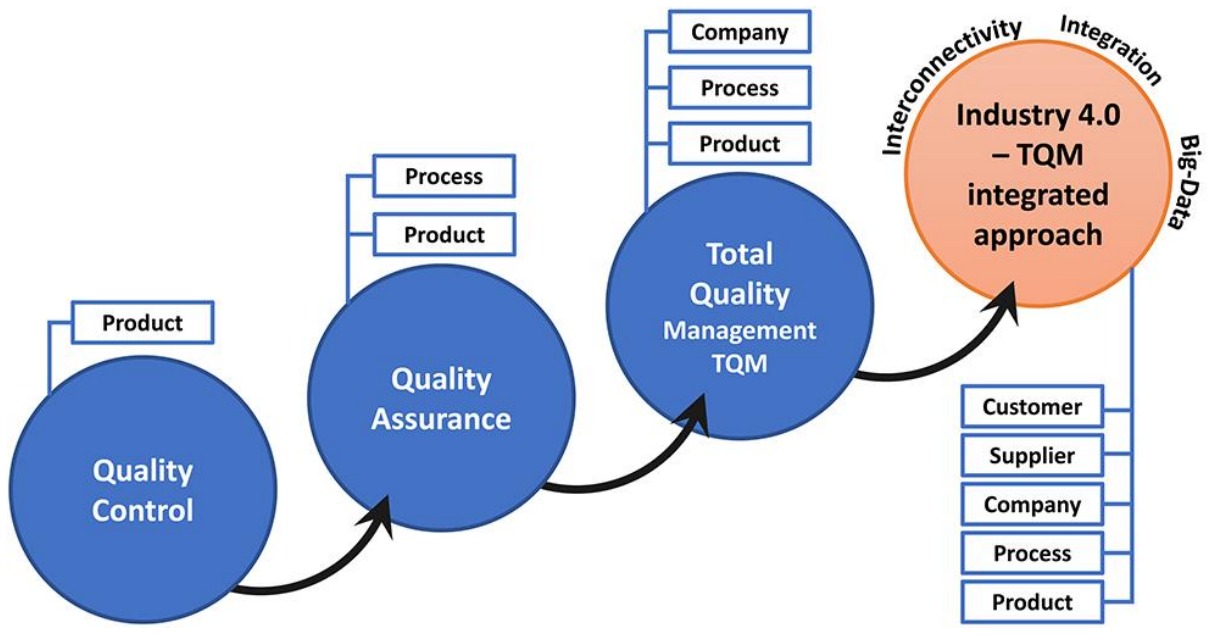

Fig. 3. The TQM Framework in the Industry 4.0 Era [37] 
Table 1. Benefits of applying industry 4.0 technologies in quality

\begin{tabular}{|c|c|}
\hline I 4.0 Technologies & Advantages and benefits \\
\hline Machine learning & $\begin{array}{l}\text { Creating a safety and quality culture through the proper execution of tasks by finding } \\
\text { levers within processes that can ensure alignment and consistency throughout the or- } \\
\text { ganization Creating a safety and quality culture through the proper execution of tasks } \\
\text { by finding levers within processes that can ensure alignment and consistency } \\
\text { throughout the organization [34]. }\end{array}$ \\
\hline $\begin{array}{l}\text { Big data and Big } \\
\text { Data Analytics }\end{array}$ & $\begin{array}{l}\text { Exploiting text analytics tools dedicated to big data to measure and analyze customer } \\
\text { satisfaction by quality professionals [55] } \\
\text { Data science and statistics: problem solving through prediction, model generation and } \\
\text { viable solutions, identification of relationships through aggregation, dynamic model- } \\
\text { ing and real-time pipelines [34]. } \\
\text { Improving the quality management approach implementation through the use of Big- } \\
\text { Data [37]. } \\
\text { Exploiting data-mining principles in smart manufacturing to improve product and } \\
\text { process quality [56]. }\end{array}$ \\
\hline Deep Learning & $\begin{array}{l}\text { Ease of defect detection by categorizing defects [20]. } \\
\text { Improving product quality through complex pattern recognition and prediction (Neu- } \\
\text { ral Networks and Deep Learning) [34]. }\end{array}$ \\
\hline $\begin{array}{l}\text { Internet of things } \\
\text { IoT }\end{array}$ & $\begin{array}{l}\text { enabling automation of sequence control, quality control and safety monitoring [57]. } \\
\text { Improving the quality assurance process efficiency through the Industrial Internet of } \\
\text { things (IIoT) and its functionalities [58], for example, performing quality audits using } \\
\text { drones connected to IoT networks [59]. }\end{array}$ \\
\hline $\begin{array}{l}\text { Artificial Intelli- } \\
\text { gence }\end{array}$ & $\begin{array}{l}\text { Big data, AI, predictive software is a new type of problem solving tool seems to be a } \\
\text { new frontier for people working in the quality field [22]. } \\
\text { Making complex quality decisions [34]. }\end{array}$ \\
\hline $\begin{array}{l}\text { Other technologies } \\
\text { and techniques }\end{array}$ & $\begin{array}{l}\text { New technologies such as RFID and AutoID: reducing counterfeiting through prod- } \\
\text { uct traceability and effective communication, as well as increasing quality and effi- } \\
\text { ciency by providing detailed information in real time [60][55] and allowing a mis- } \\
\text { take-proof for purchases and minimizing quality issues related to incorrectly pur- } \\
\text { chased parts, since purchase orders are automatically loaded with the required parts, } \\
\text { when inventory levels are low [51] [55]. } \\
\text { Blockchain: Contributing to ensure data quality, trust and developing a quality cul- } \\
\text { ture through continuous monitoring that allows the authorization of transactions that } \\
\text { meet quality objectives [34]. } \\
\text { Smart sensors: ensuring product quality control [37]. } \\
\text { ERP systems: meeting future research challenges in the Industry } 4.0 \text { era [2]. } \\
\text { CAQ (Computer Aided Quality) systems: enabling better management of quality data } \\
\text { variety. [61]. } \\
\text { Závadská and Závadský [40] presented the advantages of a collection of specific in- } \\
\text { dustry } 4.0 \text { technologies of which we have outlined those that can participate in the } \\
\text { quality improvement } \\
\text { - Management of non-compliance by using smartwatches; } \\
\text { - Management of non-compliance, quality control, change management, dispatch } \\
\text { and handling through the use of smart glasses; } \\
\text { - Virtual reality simulation will be a standard technology in product development and } \\
\text { continuous improvement. }\end{array}$ \\
\hline
\end{tabular}

According to the surveys conducted by the research company LNS, most manufacturing companies will need to be transformed to Industry 4.0 including the conversion of quality management to Quality 4.0 [36]. This smart quality will enable intelligent monitoring and diagnosis, real-time decision making and automatic tracking of equipment and materials, especially for processes that have become more volatile and 
complex [39],also a prediction which states that within five years smart gloves will be most commonly used for quality control, shipping and handling [40].

In the quality 4.0 era, quality professionals will be more able to have responses and solutions on product robustness, process excellence, customer satisfaction, new product development risks, traceability and transparency [41]. However, they must be informed about the quality management developments and this new trend "Quality 4.0" where its integration often involves external consultants [42].

\subsection{Management Methodologies with the industry 4.0}

In this new digital environment, Industry 4.0 is experiencing the existence and the support of a multifaceted set of management concepts, tools and approaches aimed at achieving operational excellence. This excellence vision leads manufacturing leaders to confront a myriad of constantly evolving challenges[43] and during this fourth revolution various changes in all aspects of management, both internally and externally within the relationships with all the ecosystem actors in which the company operates [3]. From this perspective, the literature suggests the best management practices for companies which are ready for the fourth industrial revolution. These practices make smart companies with smart employees, with a climate of innovation and learning, adding that these factors develop the capabilities that successfully manage overall business facing the globalization [44].

Moreover, operations management has been witnessing changes, improvements and a strengthening with the emergence of the industry 4.0, which is known by an immense production of data and by a highly developed tools and technologies. Moreover, to manage operations in this environment which has become increasingly complex, connected and rapidly changing, it is necessary to know and learn how to use these new technologies and develop cognitive skills that generate the wisdom and knowledge that they will need to make better decisions and to optimize processes, since they are the key characteristics in operations management [45]. On the other hand, today, we meet a multitude of operations management concepts and improvement tools proving a significant impact on the industrial environment, such as lean and agile manufacturing, sustainability, six sigma, Business Process Reengineering (BPR) and other multipurpose tools.

The interaction of these management concepts with industry 4.0 has allowed them to benefit from digitalization and from the new technologies [46]. Lean Manufacturing and Lean Six Sigma are two examples that have benefited from this revolution by improving their tools and by using new technologies in their implementations.

For technology exploitation, the interaction of Lean tools with Big Data Analytics, virtual simulation, the Cloud, and augmented reality have digitized and improved Just in Time concept to Just in Time 4.0 (JIT 4.0) and this is the case for Kaizen 4.0, Kanban 4.0, Poka-Yoke 4.0, Value Stream Mapping 4.0 (VSM 4.0) and Total Productive Maintenance 4.0 (TPM 4.0) [47] (see table 2) [48] to have the potential to be connected, intelligent and easy to implement. In addition, Industry 4.0 offers new techniques and tools that can be solutions in Lean projects [49], [50], as they can participate in the stabilization and support of the implementation of its principles [51]. They also enable 
real-time data collection throughout the value chain, and the IoT allows different processes to be fed in real time via the exploitation of cognitive algorithms [52].

Table 2. Lean tools before and after industry 4.0

\begin{tabular}{|l|l|}
\hline \multicolumn{1}{|c|}{ Tool before industry 4.0 } & \multicolumn{1}{c|}{ Tool with industry 4.0 } \\
\hline $\begin{array}{l}\text { Kanban: tool used to pull the production that } \\
\text { means we don't produce if only we need with the } \\
\text { necessary quantity. this system works with the } \\
\text { cards and kanban boards }\end{array}$ & $\begin{array}{l}\text { E-Kanban Systems: new virtual kanban system recog- } \\
\text { nized automatically via sensors or by the utilization of } \\
\text { active RFID tag which linked to the company facility's } \\
\text { wireless LAN }\end{array}$ \\
\hline $\begin{array}{l}\text { Poka-yoke: devices to eliminate production errors } \\
\text { and human error }\end{array}$ & $\begin{array}{l}\text { Automation in Error-Proofing: interconnected by bar } \\
\text { code scanners, electric fastening tools and RFID tags }\end{array}$ \\
\hline $\begin{array}{l}\text { Standardized work: creating the best practice of a } \\
\text { process usually through lessons learned }\end{array}$ & $\begin{array}{l}\text { Augmented Reality based work standardization: with } \\
\text { augmented reality we can use 3D information from in- } \\
\text { dustrial Digital Mock-Up to elaborate standards }\end{array}$ \\
\hline $\begin{array}{l}\text { Heijunka: a method for leveling the production by by } \\
\text { converting customer orders into smaller, regular } \\
\text { batches }\end{array}$ & $\begin{array}{l}\text { Digitized Heijunka: displays with graphical user inter- } \\
\text { faces GUI which are linked to MES and the production } \\
\text { line }\end{array}$ \\
\hline $\begin{array}{l}\text { Total Productive Maintenance (TPM): support } \\
\text { production and quality through the availability of } \\
\text { machines, equipment and processes }\end{array}$ & $\begin{array}{l}\text { predictive maintenance: By the use of the augmented } \\
\text { reality and sensors to detect before failure the abnor- } \\
\text { mal conditions }\end{array}$ \\
\hline
\end{tabular}

These Industry 4.0 benefits and solutions will support companies in becoming "lean" without having to "strive to become lean."[53]. Finally, the synergy between the two concepts "industry 4.0" and "lean" must be considered a new concept aiming at operational excellence as Lean focuses on the waste elimination to accelerate the physical flows and industry 4.0 aims at accelerating the informational flows [54, p. 0].

Also, the informational flows and data in LSS projects play a very important role, especially since most of the six sigma methodology tools are purely statistical tools. The amount of data available is growing rapidly, which provides opportunities to improve each phase of the famous DMAIC LSS roadmap and to consolidate its applicability in the modern data era [62]. However, LSS tools are still unable to process the voluminous data produced by Industry 4.0 technologies, yet BDAs in LSS projects contribute to the improvement of quality, processes, supply chain, profit, customer satisfaction [63] and its use has been increasingly established due to its contribution to accelerating the process of extracting key information from Big Data [64]. Not only BDAs that can positively influence LSS, but other technologies can also be called during each phase of DMAIC to improve the implementation results that were previously thought unattainable. In brief, Industry 4.0, IoT and Lean Six Sigma create an absolutely autonomous supply chain with an ideal process flow, highly optimized and free of waste and defects [21].

The SCM has taken in the industry 4.0 context several more names like Internet of Things, Supply Chain 4.0, E-Supply Chain, digital supply network (DSN), E-logistics, or Logistics 4.0 where industry 4.0 increases the automation and digitization of manufacturing, creates a digital process to facilitate the interactions between all company parts [65] and this combination can influence by advancing the operational intelligence of the production network and end customer loyalty. Adding that SCM 4.0 creates 
competitive advantage from product supply and availability, cost reduction and market share increase [66].

these benefits are gained through new technologies exploited within the SC, e.g. IoT makes SC management more efficient, Blockchain technology allows real-time tracking and improvement of passengers and goods throughout the SCM, CC assimilation promotes cooperation among SC members, etc [67]. In addition, Industry 4.0 itself helps industries integrate actions to protect and control the environment by converting supply chains to sustainable supply chains 4.0 [68], on condition that the I4.0 potential is understood through a successful adoption and diffusion of its new technologies [69].

\section{Conclusion}

Industry 4.0 has transformed the perspective of many concepts where companies must understand the influence and impact of its adoption as well as the adoption of different technologies that provide a power that was never attainable. Today, the search for operational excellence requires companies to take advantage of the concepts and tools that exist today.

Operations management and quality have also benefited from this revolution, with this article we strive to address the positive influence of Industry 4.0. A literature review on the influence of new technologies and big data analytics to force and improve quality by detailing the effect of several technologies (either for specific or for common use) and how industry 4.0 can participate in achieving quality 4.0. Moreover a set of characteristics related to the new quality 4.0 concept is described.

Furthermore, we describe the effect on several concepts of operations management and more precisely on Lean and its toolbox (Kaizen, Kanban, Poka-Yoke, Value Stream Mapping VSM and Total Productive Maintenance TPM), Lean Sigma and Supply Chain Management. We have also discussed the different new advantages given by Industry 4.0 either in the big data processing or in the use of the new technologies.

This paper deals mainly with the bright side of Industry 4.0 concerning quality and operations management, but it does not deal with the risks related to the implementation of Industry 4.0 and the use of its new technologies, the obstacles related to the work in these new conditions, etc. Industry 4.0 as a concept will be an essential element in all companies, but it is necessary to study well the knowledge related to this context before starting this digital transition. But the literature need more research on this new revolution and questions that not yet answered by industrials and researchers. In addition, in this Industry 4.0 context, we need to examine how well the existing theory is representative of talent management [70].

As a research perspective, we plan to study the negative effect of Industry 4.0 again on quality and operations management. Then, the realization of a survey concerning the adoption of the solutions of the industry 4.0 in the same context of the quality and the management of the operations where the companies of the north of Africa will be our target of studies especially to detect the limits and the obstacles which prevent them to take advantage of this new powerful revolution. 


\section{$5 \quad$ References}

[1] B. Jabir and N. Falih, "Digital agriculture in Morocco, opportunities and challenges," in 2020 IEEE 6th International Conference on Optimization and Applications (ICOA), Beni Mellal, Morocco, Apr. 2020, pp. 1-5. https://doi.org/10.1109/icoa49421.2020.9094450

[2] H. Foidl and M. Felderer, "Research Challenges of Industry 4.0 for Quality Management," in Innovations in Enterprise Information Systems Management and Engineering, vol. 245, M. Felderer, F. Piazolo, W. Ortner, L. Brehm, and H.-J. Hof, Eds. Cham: Springer International Publishing, 2016, pp. 121-137. https://doi.org/10.1007/978-3-319-32799-0_10

[3] M. Piccarozzi, B. Aquilani, and C. Gatti, "Industry 4.0 in Management Studies: A Systematic Literature Review," Sustainability, vol. 10, no. 10, p. 3821, Oct. 2018, https://doi.org/ $\underline{10.3390 / \text { su10103821 }}$

[4] Poznan University of Technology, Poznan, Poland, Faculty of Engineering Ubonratchathani University, Ubon Ratchathani, Thailand, M. Kosacka-Olejnik, and R. Pitakaso, "Industry 4.0: state of the art and research implications," Logforum, vol. 15, no. 4, pp. 478-485, Dec. 2019, https://doi.org/10.17270/j.log. 2019.363

[5] A. Albers, B. Gladysz, T. Pinner, V. Butenko, and T. Stürmlinger, "Procedure for Defining the System of Objectives in the Initial Phase of an Industry 4.0 Project Focusing on Intelligent Quality Control Systems," Procedia CIRP, vol. 52, pp. 262-267, 2016, https://doi.org/10.1016/j.procir.2016.07.067

[6] E. Hozdić, "Smart Factory for Industry 4.0: A Review," p. 8.

[7] D. Tran Anh, K. Dąbrowski, and K. Skrzypek, "The Predictive Maintenance Concept in the Maintenance Department of the 'Industry 4.0' Production Enterprise," Foundations of Management, vol. 10, no. 1, pp. 283-292, Dec. 2018, https://doi.org/10.2478/fman-2018-0022

[8] T. A. Eppes, I. Milanovic, R. Jamshidi, and D. Shetty, "Engineering Curriculum in Support of Industry 4.0," Int. J. Onl. Eng., vol. 17, no. 01, p. 4, Jan. 2021, https://doi.org/10.3991 lijoe.v17i01.17937

[9] J. D. Contreras, J. I. Garcia, and J. D. Diaz, "Developing of Industry 4.0 Applications," Int. J. Onl. Eng., vol. 13, no. 10, p. 30, Nov. 2017, https://doi.org/103991/ijoe.v13i10.7331

[10] Instytut Nauk Ekonomicznych PAN and L. Pietrewicz, "Technology, Business Models and Competitive Advantage in the Age of Industry 4.0," PZ, vol. 2/2019, no. 82, pp. 32-52, May 2019, https://doi.org/10.7172/1644-9584.82.2

[11] M. Saturno, V. Moura Pertel, F. Deschamps, and E. De Freitas Rocha Loures, "Proposal of An Automation Solutions Architecture For Industry 4.0," dtetr, no. icpr, Mar. 2018, https://doi.org/10.12783/dtetr/icpr2017/17675

[12] A. Rojko, "Industry 4.0 Concept: Background and Overview," Int. J. Interact. Mob. Technol., vol. 11, no. 5, p. 77, Jul. 2017, https://doi.org/10.3991/ijim. v11i5.7072

[13] J. Sinay and Z. Kotianová, "Automotive Industry in the Context of Industry 4.0 Strategy," TRANSACTIONS of the VŠB - Technical University of Ostrava, Safety Engineering Series, vol. 13, no. 2, pp. 61-65, Sep. 2018, https://doi.org/10.2478/tvsbses-2018-0014

[14] J. P. E. De Souza, J. M. Alves, and M. B. Silva, "Quality Improvement in the Aerospace Industry: Investigation of the Main Characteristics," IREME, vol. 8, no. 5, p. 893, Sep. 2014, https://doi.org/10. 15866/ireme.v8i5.2934

[15] Health Foundation (Great Britain), Evaluation: what to consider : commonly asked questions about how to approach evaluation of quality improvement in health care. 2015.

[16] M. Chaitanya, S. Chinni, M. Jyothia, and Y. P. Reddy, "The Importance Of Quality Management System For a Successful Health Care Industry: A Review Based on Case Studies," p. 7, 2018 . 
[17] A. Petcharit, P. Sornsaruht, and P. Pimdee, "An Analysis of Total Quality Management (TQM) within the Thai Auto Parts Sector," Int. J. Onl. Eng., vol. 16, no. 02, p. 131, Feb. 2020, https://doi.org/10.3991/ijoe.v16i02.11917

[18] M. Rana, X. Zhang, and S. A. Akher, "Determination of Factors and Quality Control of Car Painting Based on FMEA and SPC.V2," Modern Mechanical Engineering, p. 20. https://doi.org/10.4236/mme.2018.82011

[19] H. Mohamad, R. Jenal, and D. Genas, "Quality Control Implementation in Manufacturing Companies: Motivating Factors and Challenges," in Applications and Experiences of Quality Control, O. Ivanov, Ed. InTech, 2011, https://doi.org/10. 5772/15997

[20] J. Villalba-Diez, D. Schmidt, R. Gevers, J. Ordieres-Meré, M. Buchwitz, and W. Wellbrock, "Deep Learning for Industrial Computer Vision Quality Control in the Printing Industry 4.0," Sensors, vol. 19, no. 18, p. 3987, Sep. 2019, https://doi.org/10. 3390/s19183987

[21] A. Jayaram, "Lean six sigma approach for global supply chain management using industry 4.0 and IIoT," in 2016 2nd International Conference on Contemporary Computing and Informatics (IC3I), Greater Noida, India, Dec. 2016, pp. 89-94. https://doi.org/10. 1109/ ic3i.2016.7917940

[22] A. Chiarini, "Industry 4.0, quality management and TQM world. A systematic literature review and a proposed agenda for further research," TQM, vol. 32, no. 4, pp. 603-616, Jun. 2020, https://doi.org/10.1108/tqm-04-2020-0082

[23] R. Godina and J. C. O. Matias, "Quality Control in the Context of Industry 4.0," in Industrial Engineering and Operations Management II, vol. 281, J. Reis, S. Pinelas, and N. Melão, Eds. Cham: Springer International Publishing, 2019, pp. 177-187. http://doi.org/10.1007/ 978-3-030-14973-4_17

[24] R. Wolniak, "Main functions of operation management," Production Engineering Archives, vol. 26, no. 1, pp. 11-14, Mar. 2020, https://doi.org/10.30657/pea.2020.26.03

[25] J. V. A. Costa, M. C. F. de Oliveira, and P. W. S. de Oliveira, "Lean Office application in management flow of a billing department," IJETT, vol. 67, no. 11, pp. 23-26, Nov. 2019, https://doi.org/10.14445/22315381/ijett-v67i11p204

[26] R. W. Schmenner and M. L. Swink, "On Theory in Operations Management,” p. 29.

[27] E. Battistoni, A. Bonacelli, A. F. Colladon, and M. M. Schiraldi, "An Analysis of the Effect of Operations Management Practices on Performance," p. 11.

[28] H. Rifqi, S. B. Souda, A. Zamma, and O. Badder, "Lean Six Sigma in agribusiness: A Case Study in a Cookie Production Plant," IJETT, vol. 69, no. 1, pp. 56-65, Jan. 2021, https://doi .org/10.14445/22315381/ijett-v69i1p209

[29] C. A. Voss, "Operations management - from Taylor to Toyota - and Beyond?," Br J Management, vol. 6, no. s1, pp. S17-S29, Dec. 1995, https://doi.org/10.1111/j.1467$\underline{8551.1995 . t b 00135 . x}$

[30] A. Nedyalkov, "Aspects of Operations Management of Services," p. 11.

[31] N. Slack, M. Lewis, and H. Bates, "The two worlds of operations management research and practice," p. 23

[32] A. Zonnenshain and R. S. Kenett, "Quality 4.0-the challenging future of quality engineering," Quality Engineering, vol. 32, no. 4, pp. 614-626, Oct. 2020, https://doi.org/10.1080/ $\underline{08982112.2019 .1706744}$

[33] Gregory H. Watson, "Digital Hammers and Electronic Nails: Tools of the Next Generation." Quality Progress, vol. pp. 21-26., no. Jul 1998.

[34] R. Sisodia and D. V. Forero, "Quality 4.0 - How to Handle Quality in the Industry 4.0 Revolution," p. 64. 
[35] J. Ramezani and J. Jassbi, "Quality 4.0 in Action: Smart Hybrid Fault Diagnosis System in Plaster Production," Processes, vol. 8, no. 6, p. 634, May 2020, https://doi.org/10.3390/ pr8060634

[36] L. N. S. Research, “Quality 4.0 eBook.” https://blog.lnsresearch.com/quality40ebook (accessed Dec. 14, 2020).

[37] S. Sader, I. Husti, and M. Daróczi, "Industry 4.0 as a Key Enabler toward Successful Implementation of Total Quality Management Practices," Period. Polytech. Soc. Man. Sci., vol. 27, no. 2, pp. 131-140, Aug. 2019, https://doi.org/10.3311/ppso.12675

[38] J. Nenadál, "The New EFQM Model: What is Really New and Could Be Considered as a Suitable Tool with Respect to Quality 4.0 Concept?," QIP Journal, vol. 24, no. 1, p. 17, Apr. 2020, https://doi.org/10.12776/qip.v24i1.1415

[39] J. Ramezani and J. Jassbi, "A Hybrid Expert Decision Support System Based on Artificial Neural Networks in Process Control of Plaster Production - An Industry 4.0 Perspective," in Technological Innovation for Smart Systems, vol. 499, L. M. Camarinha-Matos, M. Parreira-Rocha, and J. Ramezani, Eds. Cham: Springer International Publishing, 2017, pp. 5571. https://doi.org/10.1007/978-3-319-56077-9_5

[40] Z. Závadská and J. Závadský, "Quality managers and their future technological expectations related to Industry 4.0," Total Quality Management \& Business Excellence, vol. 31, no. 78, pp. 717-741, May 2020, https://doi.org/10.1080/14783363.2018.1444474

[41] J. S. Lim, Quality Management in Engineering: A Scientific and Systematic Approach, 1st ed. Boca Raton: Taylor \& Francis, a CRC title, part of the Taylor \& Francis imprint, a member of the Taylor \& Francis Group, the academic division of T\&F Informa, plc, 2020. CRC Press, 2019. https://doi.org/10.1080/00224065.2021.1947163

[42] I. Schönreiter, "Significance of Quality 4.0 in Post Merger Process Harmonization," in Innovations in Enterprise Information Systems Management and Engineering, vol. 285, F. Piazolo, V. Geist, L. Brehm, and R. Schmidt, Eds. Cham: Springer International Publishing, 2017, pp. 123-134. https://doi.org/10.1007/978-3-319-58801-8_11

[43] J. Villalba-Diez, X. Zheng, D. Schmidt, and M. Molina, "Characterization of Industry 4.0 Lean Management Problem-Solving Behavioral Patterns Using EEG Sensors and Deep Learning," Sensors, vol. 19, no. 13, p. 2841, Jun. 2019, https://doi.org/10.3390/s19132841

[44] S. Shamim, S. Cang, H. Yu, and Y. Li, "Management approaches for Industry 4.0: A human resource management perspective," in 2016 IEEE Congress on Evolutionary Computation (CEC), Vancouver, BC, Canada, Jul. 2016, pp. 5309-5316. https://doi.org/10.1109/ cec. 2016.7748365

[45] O. Matthias, I. Fouweather, I. Gregory, and A. Vernon, "Making sense of Big Data - can it transform operations management?," Int Jrnl of Op \& Prod Mnagemnt, vol. 37, no. 1, pp. 37-55, Jan. 2017, https://doi.org/10.1108/ijopm-02-2015-0084

[46] H. Rifqi, S. Ben Souda, and A. Zamma, "Lean Maintenance 4.0: An application of the IoT Technology in the facility management industry," IJATCSE, vol. 9, no. 5, pp. 9064-9070, Oct. 2020, https://doi.org/10.30534/ijatcse/2020/311952020

[47] L. S. Valamede and A. C. S. Akkari, "Lean 4.0: A New Holistic Approach for the Integration of Lean Manufacturing Tools and Digital Technologies," Int J Math, Eng, Manag Sci, vol. 5, no. 5, pp. 851-868, Oct. 2020, https://doi.org/10. 33889/ijmems.2020.5.5.066

[48] S. Satoglu, A. Ustundag, E. Cevikcan, and M. B. Durmusoglu, "Lean Production Systems for Industry 4.0," in Industry 4.0: Managing The Digital Transformation, Cham: Springer International Publishing, 2018, pp. 43-59. https://doi.org/10.1007/978-3-319-57870-5_3

[49] M. Shahin, F. F. Chen, H. Bouzary, and K. Krishnaiyer, "Integration of Lean practices and Industry 4.0 technologies: smart manufacturing for next-generation enterprises," Int $J$ Adv 
Manuf Technol, vol. 107, no. 5-6, pp. 2927-2936, Mar. 2020, https://doi.org/10.1007/ s00170-020-05124-0

[50] S. Satoglu, A. Ustundag, E. Cevikcan, and M. B. Durmusoglu, "Lean Production Systems for Industry 4.0," in Industry 4.0: Managing The Digital Transformation, Cham: Springer International Publishing, 2018, pp. 43-59. https://doi.org/10.1007/978-3-319-57870-5_3

[51] T. Wagner, C. Herrmann, and S. Thiede, "Industry 4.0 Impacts on Lean Production Systems," Procedia CIRP, vol. 63, pp. 125-131, 2017, https://doi.org/10.1016/j.procir. $\underline{2017.02 .041}$

[52] G. Arcidiacono and A. Pieroni, "The Revolution Lean Six Sigma 4.0," International Journal on Advanced Science, Engineering and Information Technology, vol. 8, no. 1, p. 141, Feb. 2018, https://doi.org/10.18517/ijaseit.8.1.4593

[53] A. G. Uriarte, A. H. C. Ng, and M. U. Moris, "Supporting the lean journey with simulation and optimization in the context of Industry 4.0," Procedia Manufacturing, vol. 25, pp. 586593, 2018, https://doi.org/10.1016/j.promfg.2018.06.097

[54] A. Moeuf, R. Pellerin, S. Lamouri, S. Tamayo-Giraldo, and R. Barbaray, "The industrial management of SMEs in the era of Industry 4.0," International Journal of Production Research, vol. 56, no. 3, pp. 1118-1136, Feb. 2018, https://doi.org/10.1080/00207543. $\underline{2017.1372647}$

[55] K. S. P. N. Kannan and A. Garad, "Competencies of quality professionals in the era of industry 4.0: a case study of electronics manufacturer from Malaysia," IJQRM, vol. ahead-ofprint, no. ahead-of-print, Sep. 2020, https://doi.org/10.1108/ijqrm-04-2019-0124

[56] H. Oliff and Y. Liu, "Towards Industry 4.0 Utilizing Data-Mining Techniques: A Case Study on Quality Improvement," Procedia CIRP, vol. 63, pp. 167-172, 2017, https://doi .org/10.1016/j.procir.2017.03.311

[57] J. Qin, Y. Liu, and R. Grosvenor, "A Categorical Framework of Manufacturing for Industry 4.0 and Beyond," Procedia CIRP, vol. 52, pp. 173-178, 2016, https://doi.org/10. 1016/j.procir.2016.08.005

[58] M. A. Lyle, "From paper and pencil to industry 4.0: revealing the value of data through quality intelligence," vol. Vol. 10, no. pp. 25-29, 2017.

[59] D. Porto, "Rise of the drones," ASQ Quality Progress, vol. Vol. 50, no. No. 10, pp. 8-10, Oct. 2017.

[60] V. Roblek, M. Meško, and A. Krapež, “A Complex View of Industry 4.0,” SAGE Open, vol. 6, no. 2, p. 215824401665398 , Apr. 2016, https://doi.org/10. 1177/2158244016653987

[61] Jahrestagung der Gesellschaft für Qualitätswissenschaft, Qualitätsmethoden im Diskurs zwischen Wissenschaft und Praxis: Bericht zur GQW-Jahrestagung 2015 in Wuppertal. Aachen: Shaker, 2015. https://doi.org/10.1007/978-3-662-60692-6

[62] I. M. Zwetsloot, A. Kuiper, T. S. Akkerhuis, and H. de Koning, "Lean Six Sigma meets data science: Integrating two approaches based on three case studies," Quality Engineering, vol. 30, no. 3, pp. 419-431, Jul. 2018, https://doi.org/10.1080/08982112.2018.1434892

[63] H. Rifqi, A. Zamma, and S. Ben Souda, "Lean 4.0, Six Sigma-Big Data Toward Future Industrial Opportunities and Challenges: A Literature Review," in Advances on Smart and Soft Computing, vol. 1188, F. Saeed, T. Al-Hadhrami, F. Mohammed, and E. Mohammed, Eds. Singapore: Springer Singapore, 2021, pp. 201-210. https://doi.org/10.1007/978-98115-6048-4_18

[64] D. Fogarty, "Lean Six Sigma and Big Data: Continuing to Innovate and Optimize Business Processes," p. 19, 2015.

[65] M. Abdirad and K. Krishnan, "Industry 4.0 in Logistics and Supply Chain Management: A Systematic Literature Review," Engineering Management Journal, pp. 1-15, Jul. 2020, https://doi.org/10.1080/10429247.2020.1783935 
[66] G. F. Frederico, J. A. Garza-Reyes, A. Anosike, and V. Kumar, "Supply Chain 4.0: concepts, maturity and research agenda," SCM, vol. 25, no. 2, pp. 262-282, Sep. 2019, https://doi.org /10.1108/scm-09-2018-0339

[67] K. Zekhnini, A. Cherrafi, I. Bouhaddou, Y. Benghabrit, and J. A. Garza-Reyes, "Supply chain management 4.0: a literature review and research framework," BIJ, vol. ahead-ofprint, no. ahead-of-print, Sep. 2020, https://doi.org/10. 1108/bij-04-2020-0156

[68] M. Ramirez-Peña, F. J. Abad Fraga, J. Salguero, and M. Batista, "Assessing Sustainability in the Shipbuilding Supply Chain 4.0: A Systematic Review," Sustainability, vol. 12, no. 16, p. 6373, Aug. 2020, https://doi.org/10.3390/su12166373

[69] C. Bai, P. Dallasega, G. Orzes, and J. Sarkis, "Industry 4.0 technologies assessment: A sustainability perspective," International Journal of Production Economics, vol. 229, p. 107776, Nov. 2020, https://doi.org/10.1016/j.ijpe.2020.107776

[70] Z. Whysall, M. Owtram, and S. Brittain, "The new talent management challenges of Industry 4.0,” JMD, vol. 38, no. 2, pp. 118-129, Mar. 2019, https://doi.org/10.1108/jmd-06-2018$\underline{0181}$

\section{Authors}

Hanane Rifqi ENSET Mohammadia, SSDIA Laboratory, HASSAN II University, Casablanca, Morocco.

Abdellah Zamma ENSET Mohammadia, SSDIA Laboratory, HASSAN II University, Casablanca, Morocco.

Souad Ben Souda ENSET Mohammadia, SSDIA Laboratory, HASSAN II University, Casablanca, Morocco.

Mohamed Hansali Department of economics and management, HASSAN II University, Casablanca, Morocco.

Article submitted 2021-06-11. Resubmitted 2021-07-17. Final acceptance 2021-07-17. Final version published as submitted by the authors. 